\title{
Do We Need A Knowledge Community in Serbia?
}

\author{
Zoran Lovrekovic \\ Higher Education Technical \\ School of Professional Studies, \\ Novi Sad, Serbia \\ lovrekovic@vtsns.edu.rs
}

\author{
Camil Sukic \\ International University in Novi \\ Pazar, Novi Pazar, \\ Serbia
}

camil.sukic@gmail.com

\begin{abstract}
Applying the concept of knowledge management in practice is a necessary means to gain global competitiveness of an organization. By spreading this idea to the masses, the whole economies could gain competitiveness as well, on a journey from an industrial age to the knowledge age, a journey which the most developed economies had already undertaken. Internet technologies enable the creation of a virtual community, a knowledge manager, where the interaction between those who are part of this will be permanent and essential, and not occasional and formal. The idea of creating a virtual community became reality with the site www.uzns.net and this paper discusses initial experiences of creating a virtual community of this kind and also the possibilities which this initiative addresses.
\end{abstract}

Key words: virtual community, knowledge management, the knowledge age, innovation

\section{Introduction}

Virtual community is a large group of people and represents a social community with all the features of a traditional social community, except for being constituted in "virtual reality". From a purely technical point of view, this is a dynamic web site which enables its members, who are at different places and at different time, to organize and function as a community (Gibson, 1984; Rheingold, 1993). Their aim is to act together in order to solve problems of its members and the community as a whole, to provide mutual help, to collaborate and to fulfill the preset goals of the community. The technical aspect itself, i.e. physical realization of the site, is insufficient and inadequate if a virtual community does not "live" by its technical premises, as it is not enough just to build houses and buildings to create a city, it is necessary for the people to recognize the infrastructure as desirable and appropriate so that the community would "live".

Knowledge community sets a new primary goal: initiatives for knowledge management in the given field are not partial and individual any more, but are comprehensive in all of its dimensions. This site provides constant "on-line" sharing of all the activities, processes, information and

Material published as part of this publication, either on-line or in print, is copyrighted by the Informing Science Institute. Permission to make digital or paper copy of part or all of these works for personal or classroom use is granted without fee provided that the copies are not made or distributed for profit or commercial advantage AND that copies 1) bear this notice in full and 2) give the full citation on the first page. It is permissible to abstract these works so long as credit is given. To copy in all other cases or to republish or to post on a server or to redistribute to lists requires specific permission and payment of a fee. Contact Publisher@,InformingScience.org to request redistribution permission. knowledge between all the participants in a chain of creating new values in the domain to which the virtual community belongs (in this case KM-Knowledge Management). In this way, knowledge, which is otherwise "invisible" because it is fragmented, divided into segments between various participants who are involved in creating new values in the domain of KM, now becomes clearly 
visible (Lovrekovic \& Nikolic, 2004; Lovrekovic \& Ristic, 2008). The members of the community share not only data, nor just information (information is only data put into a certain context). They also share knowledge (information put into an appropriate context), as well as business and organizational processes, routines and practice, making it possible for the community to work together, to practice the culture of togetherness, to make effort in order to identify, define, and solve problems. In this way new knowledge is created faster, the process of innovation is automated, new and more effective products and services are discovered as well as new ways of distributing these products and services to users (Lovrekovic, 2003; Lovrekovic \& Ristic, 2008).

At European Summit in Lisboa in March 2000 (Lisbon, 2000) and Europe Summit in Barcelona in March 2002 (Feantsa, 2002), it was concluded that information and knowledge are vital for promoting innovation and achieving competence and success in a modern society which is based on knowledge and in which organizational environment changes very fast. One of the conclusions stated in Barcelona says that one of Europe's goals is to reach "a competitive society based on knowledge" and in doing so, to concentrate on education through systematic training, and to adjust to "demands of knowledge community and needs to improve the quality of employees". These goals have to be achieved by improving "basic qualifications, development of computer literacy and lifelong learning". Similar conclusions could be found in UNICE Benchmarking Report 2000 (Montano, 2005, p. 256).

While searching for a way to enhance technological development and the development of the society in general, knowledge is identified as the main resource. There is a change in the paradigm in the countries with highly developed economies - from the era where competitive advantage meant to possess information, the developed world moves to the era where competitive advantage means to have the ability to create new knowledge, especially that knowledge which results in:

- new technologies

- new products

- increased and even decisive influence of a customer on a product/service

- new organizational processes

- new quality

- new, additional customer satisfaction, because it is exactly what helps an organization to gain competitive advantage over its rivals

Basically, knowledge, defined this way, is a piece of information which changes something or someone, either by becoming an incentive for some action or by making a person (or an organization) capable of working in a different way or more efficiently (Lovrekovic, 2004). The aim of knowledge management is to maintain the balance between tacit and explicit knowledge, and to manage them so that more innovation, better effectiveness (doing the right things) and better efficiency (doing the right things the right way) are achieved (Lovrekovic, 2004; Lovrekovic \& Ristic, 2008).

To make it possible to share knowledge, and not only information, through a web site, that web site should be used for sharing complete (organizational) processes in which information is used. Also the site should be used for continuous joint analysis, evaluation and information and knowledge utilization, with a view to creating new operational knowledge which would result in better effectiveness, efficiency and innovativeness (Lovrekovic \& Nikolic, 2004; Lovrekovic \& Ristic, 2008).

In present times, a new business revolution is taking place in a modern world. There is a shift of eras affecting the human kind. Industrial age becomes a thing of the past, outdated and inappro- 
priate for new conditions and demands the world is facing, and is replaced by the knowledge age. It seems obvious that, in times like these, the only possible way out of the crisis our society is in, is to learn to work in "a new way", to abandon the concepts of industrial way of doing business and to "enter" the knowledge age. A very small number of people in our country think about production. They make a living by selling belongings and assets which they acquired by working very hard and they sold almost everything they could. A negligible percentage of population is aware of that new business revolution which passes us by and for that reason we become doomed. In these circumstances, one (and maybe the only?) possible way out is to create a germ of a new society i.e. a knowledge community, hoping that it would grow strong and fast enough, enlighten the society and lead it in the right direction.

The ability to master the production of something which could compete with "Toyota" (instead of producing "Zastava") is achieved neither easily, nor simply. Additionally, all of those who think that we cannot do that because we do not have "the money" are leading us to perdition. We cannot do that because we do not have the necessary knowledge, skills, abilities and foremost, we do not have the appropriate attitudes.

\section{Realization in Practice}

So, how do we create "a knowledge community"? It would lead to creating much needed knowledge, skills, abilities and appropriate attitudes. Consequently, our organizations would finally become globally competitive and our society, once hungry for knowledge and disorientated would transform into a capable and content one.

The first step is to build appropriate information communication infrastructure which could sustain functioning of this community. A dynamic web site is created for that purpose. Homepage of this site (www.uzns.net) is shown in Figure 1.

Homepage gives a short answer to the question 'why manage knowledge?' At the bottom of the homepage there is a link which leads to the rest of the text given here as short news. On the left side of the page there is a navigation menu, with following links:

- Homepage

- News

- Association

- Forum instructions

- Forum

- Contact

- Seminars and training

- Window into future 


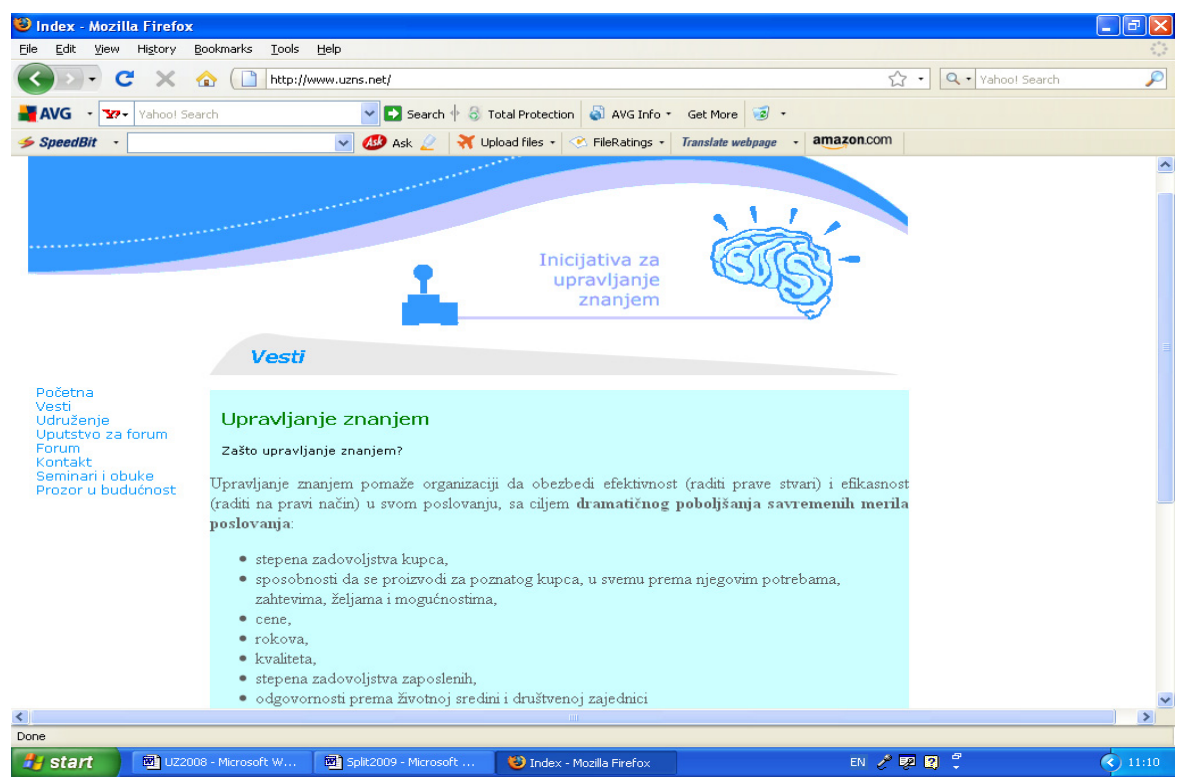

Figure 1: Homepage of 'Knowledge community' web site

The page "Association" contains the basic information about citizens association "Initiative for knowledge management" which is "the owner" of the site. It also states goals and tasks of the association. The last paragraph of this page states: "We invite you to contact us and give your suggestions for collaboration, share your ideas, comments and your experiences. Let's build knowledge chain together. It is high time for us to learn how to succeed in "the knowledge age". Can "Zastava" become "Toyota"? Our answer is not only that it can, but it HAS TO, if we want the opportunity to succeed in the future!"

"Contact" is a page with the name of the person who takes care and made coordination about all activities through this site, his/her telephone number and an email address.

The page "Forum" is a part of the site that the creators had most hopes for. It is here that the members of the community can exchange their experiences, jointly solve problems, ask questions and give answers. Figure 2 shows what the page looks like:

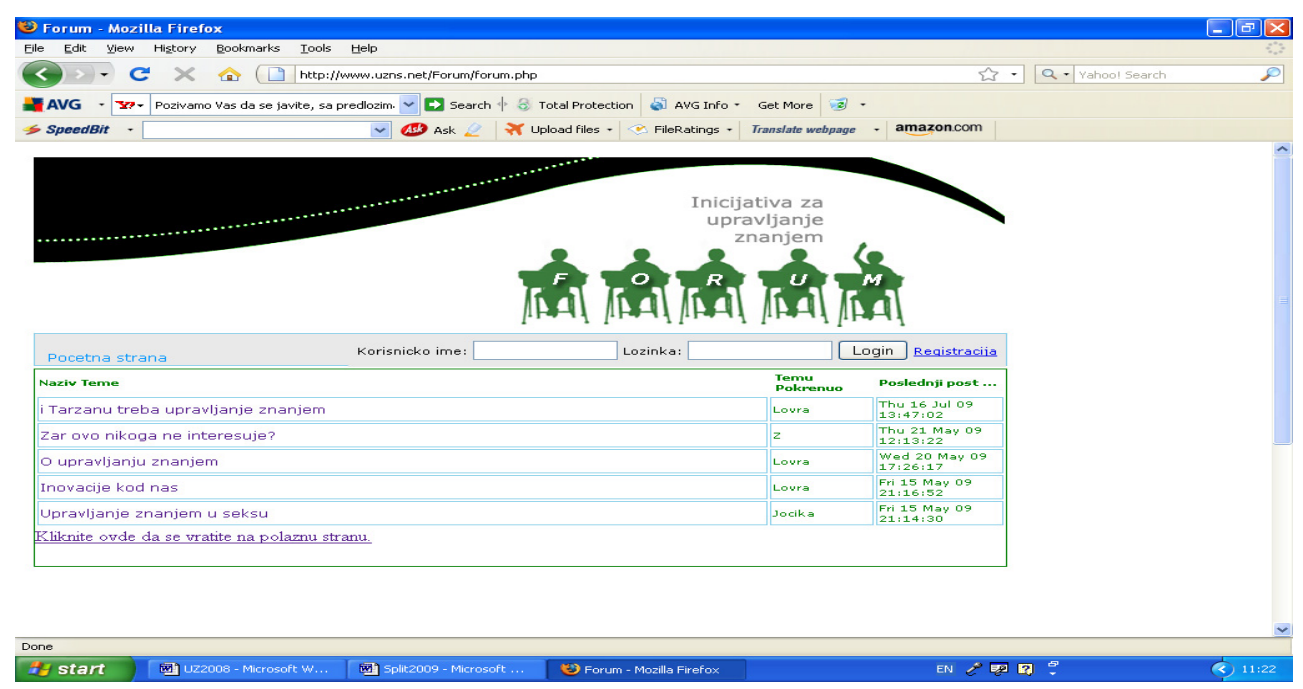

Figure 2: Community members' forum 
By clicking on some of the topics, you open a chosen topic, as shown in Figure 3:

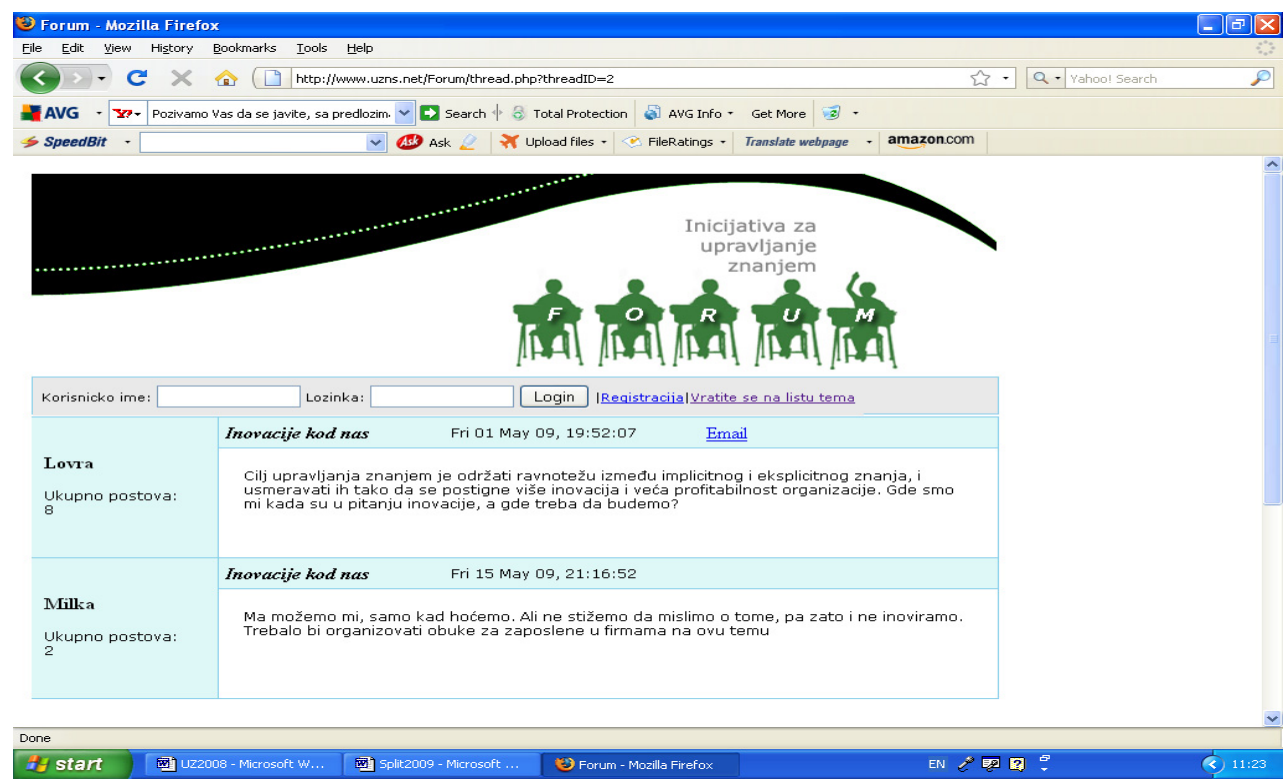

Figure 3: Forum topic

Two topics are posted on the forum to begin with:

- Can the concept of "knowledge management" make the managers in our firms do not perceive "surplus of staff" as such but as "shortage of work"?

- The aim of knowledge management is to maintain the balance between tacit and explicit knowledge, and to manage them so that more innovation and a higher profitability of an organization are achieved. Where do we stand when innovation is in question, and where should we be?

About 200 people were directly informed by email about the set up of this site. The people informed were all of the participants in the Conference "On the Road to the Knowledge Age" (Lovrekovic, 2003, 2004; Lovrekovic \& Nikolic, 2004; Lovrekovic \& Ristic, 2008), all of the acquaintances, friends, and business partners of the members of the association, students and other people who are familiar with this subject and recognize its importance for our society. All of them were asked to spread this information through multi-level-marketing (MLM), i.e., to send emails to the others who could be interested in this subject. We expected that a large number of people would contribute to the discussions on the forum and that it would be "the spark" for a community to be created. Contrary to our expectations, the response was extremely bad. Only few people took part in the discussion on the forum. The disappointment was that much bigger since the forum is of an "open" type - everyone can register and post a new topic!

When discussing the reasons people are not interested in this with the members of the NGO "Knowledge Management Initiative", who are trying to establish this virtual community, we came to a conclusion that most likely they do not know how to use this kind of forum. Therefore "the instruction how to use the forum" was created and added as a PDF file. Consequently, "forum instructions" link was added as well. This did not help increase participation in the discussions on the forum. 
The next step was to add more intriguing topics, such as:

"I am interested in participating in some project about "knowledge management in sex". Sex is one of the most significant subjects of human kind, so it must be that knowledge management is crucial here, and not just how to manage your "tool".

If the administrator allows, I'd like to post a survey on that subject, and I am especially looking forward to responses of female colleagues.

Best wishes,

Jocika"

Only two posts on this subject, and one is particularly interesting, signed by Milka:

"All you men are the same. All you do is talk about sex. And who is going to work? No one! That's the problem. All you do is talk here, and no one does any work!

Jocika, if you need Milka to work together with you to the benefit of the human kind, I am ready for collaboration!"

Next attempt to make people more interested in participating was to post a silly topic - the topic was "Even Tarzan needs knowledge management" - this did not help either.

One of the links is "seminars and training". This link lists programs of a huge number of seminars in the field of knowledge management, management and application of IT in business that this association offers. It has been 4 months since the site was created, and so far no one has ordered any of the courses or trainings.

Then, steps were taken to inform other institutions about the existence of this site, and its goals, and those institutions were:

- Fund for an open society

- Provincial secretariat for science

- Ministry of science and technological development

- The Faculty of economics in Belgrade, Subotica, Zagreb, Split, Podgorica...

- All faculties of management in Serbia

- The faculties of management in Bosnia and Herzegovina, Croatia...

- National Employment Service

- Chamber of Commerce and Industry of Serbia

- Chamber of Commerce and Industry of Vojvodina

We have received no responses from any of these institutions, nor the confirmation that they have received our email.

The link "Window into future" leads to the page shown in Figure 4. The association is, among other things, registered as a publishing business, and the first monograph it has published was "Internet Programing - html, css, javascript, mysql, php". The monograph contains links to the content of the book, the whole first chapter is in PDF format, and there is also a possibility of an on-line order. It is very surprising that many faculties which offer courses in IT, and even some which claim to be "the first and the original ones" totally ignored publication of this contemporary and insightful monograph about the most advanced software technologies for creating web business applications, and they did not order even a single copy. This was as disappointing as the 
lack of participation in discussions on the forum of people who (supposedly) deal with knowledge management.

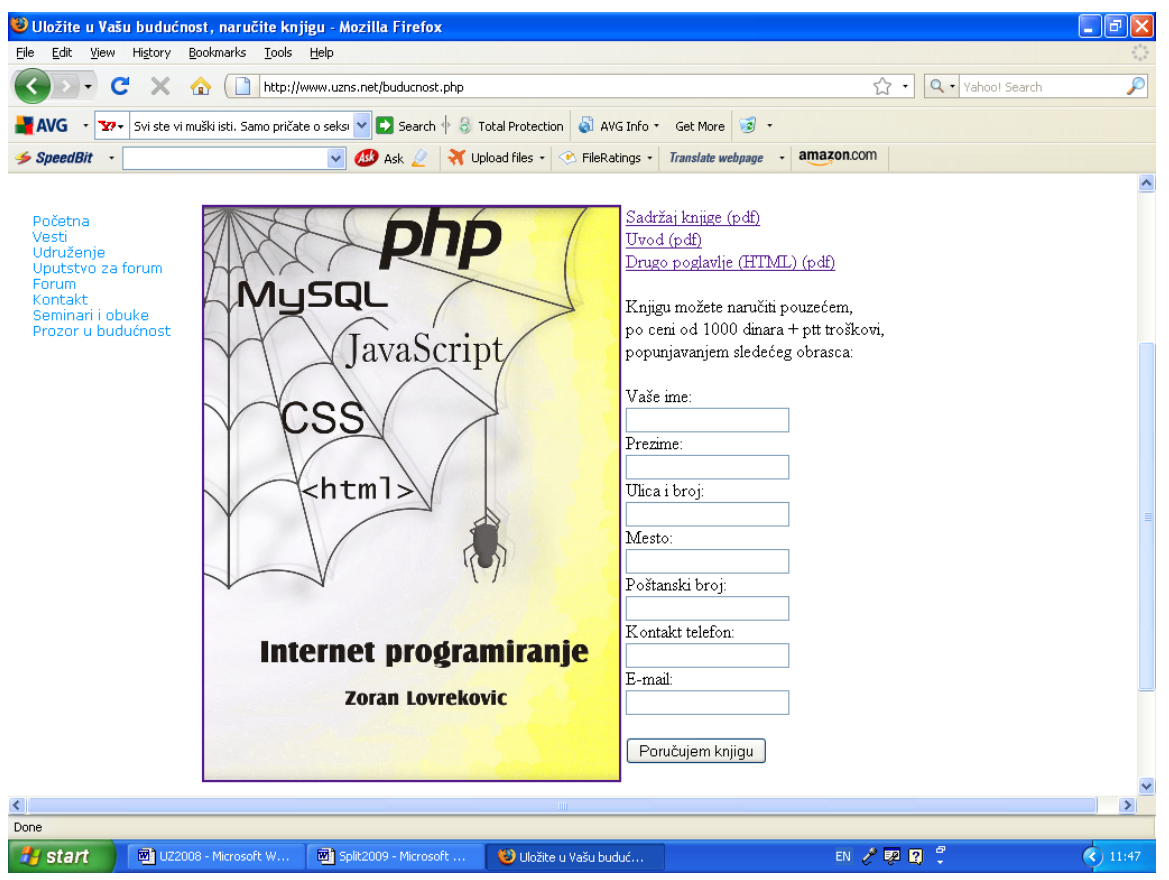

Figure 4: Window into future

\section{Statistic Indicators}

Figure 5 shows the number of visits to the site every month, from the set up on 26 April 2006 to 8 August 2009.

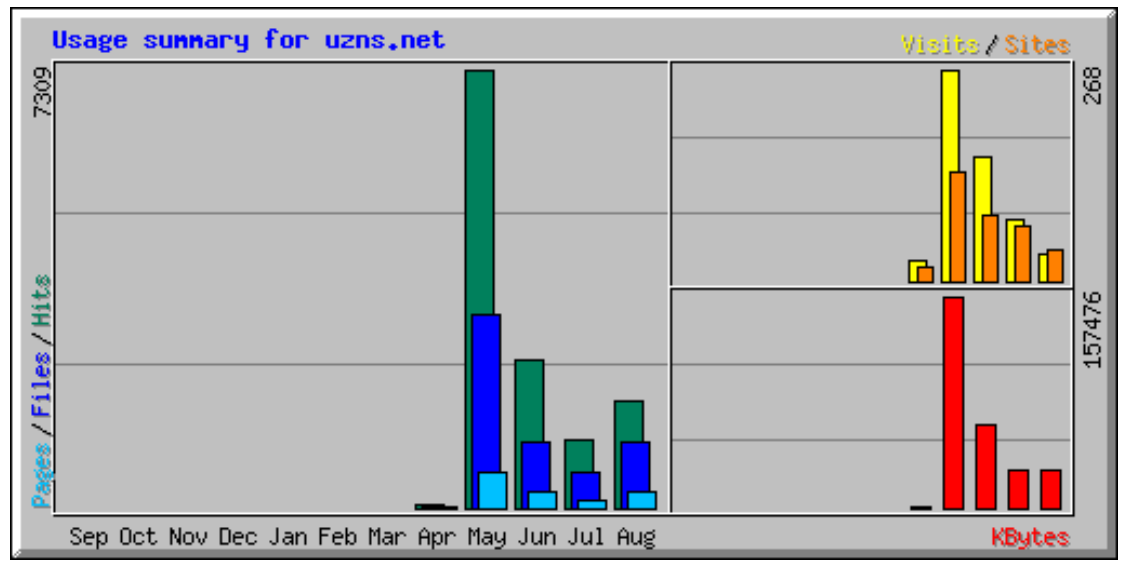

Figure 5: visits to the site www.uzns.net

The number of visits was the highest in May, after informing potential participants by email messages for the first time. Later on, number of visits decreases drastically, which indicates that the visitors did not recognize any benefits of visiting this site. 


$\begin{array}{llllll}\text { Month } & \begin{array}{l}\text { Unique } \\ \text { tors }\end{array} & \begin{array}{c}\text { visi- Number } \\ \text { visits }\end{array} & \text { of Pages } & \text { Hits } & \text { Bandwidth } \\ \text { Jan 2009 } & 0 & 0 & 0 & 0 & 0 \\ \text { Feb 2009 } & 0 & 0 & 0 & 0 & 0 \\ \text { Mar 2009 } & 0 & 0 & 0 & 0 & 0 \\ \text { Apr 2009 } & 10 & 14 & 16 & 16 & 80.64 \mathrm{~KB} \\ \text { May 2009 } & 124 & 232 & 2070 & 3777 & 98.58 \mathrm{MB} \\ \text { Jun 2009 } & 67 & 115 & 647 & 1073 & 35.36 \mathrm{MB} \\ \text { Jul 2009 } & 52 & 62 & 279 & 496 & 13.13 \mathrm{MB} \\ \text { Aug 2009 } & 19 & 25 & 776 & 1453 & 22.49 \mathrm{MB} \\ \text { Sep 2009 } & 0 & 0 & 0 & 0 & 0 \\ \text { Oct 2009 } & 0 & 0 & 0 & 0 & 0 \\ \text { Nov 2009 } & 0 & 0 & 0 & 0 & 0 \\ \text { Dec 2009 } & 0 & 0 & 0 & 0 & 0 \\ \text { Total } & 272 & 448 & 3788 & 6815 & 169.63 \mathrm{MB}\end{array}$

Figure 6: Tabular presentation of information about visitations to the site

Even in May, the month with the most visits, we can see that there were only 124 visitors, some of which visited the site several times (total of 232 visits). They opened some of the pages 2070 times. So, those who visited the site opened all or most of its pages i.e. they spend some time on this site. Dataflow is modest, just 100MB. But we are a country of "voyeurs", so when there is nothing new to see, we go somewhere else to "watch", instead of taking part ourselves.

Therefore, since nothing especially new went on on the site (nothing ever happens if we only watch, and there was obviously some reason which prevented our visitors from participating), number of visits in the following months collapsed (number of visits halved compared to May). In the first eight days in August there were 19 visitors, 448 visits which indicates that these are fateful visitors although their number is scarce.

The highest number of visits occured on Friday, and a bit surprisingly, on Tuesday, shown in Figure 7. 


\begin{tabular}{llll} 
Day & Pages & Hits & Bandwidth \\
Mon & 55 & 158 & $2.02 \mathrm{MB}$ \\
Tue & 242 & 351 & $8.58 \mathrm{MB}$ \\
Wed & 129 & 332 & $2.88 \mathrm{MB}$ \\
Thu & 31 & 114 & $767.37 \mathrm{~KB}$ \\
Fri & 292 & 452 & $7.22 \mathrm{MB}$ \\
Sat & 8.50 & 8.50 & $37.26 \mathrm{~KB}$ \\
\hline Sun & 10 & 29 & $1000.17 \mathrm{~KB}$
\end{tabular}

Figure 7: Visits to the site by days

During the day, visitation to the site is the highest between 8 and $11 \mathrm{PM}$, and between $9 \mathrm{AM}$ and $1 \mathrm{PM}$

On 12 August 2009 a distance learning system "Moodle" was set up, with the first on-line course called "Doing business in the knowledge age" (see Figure 8).

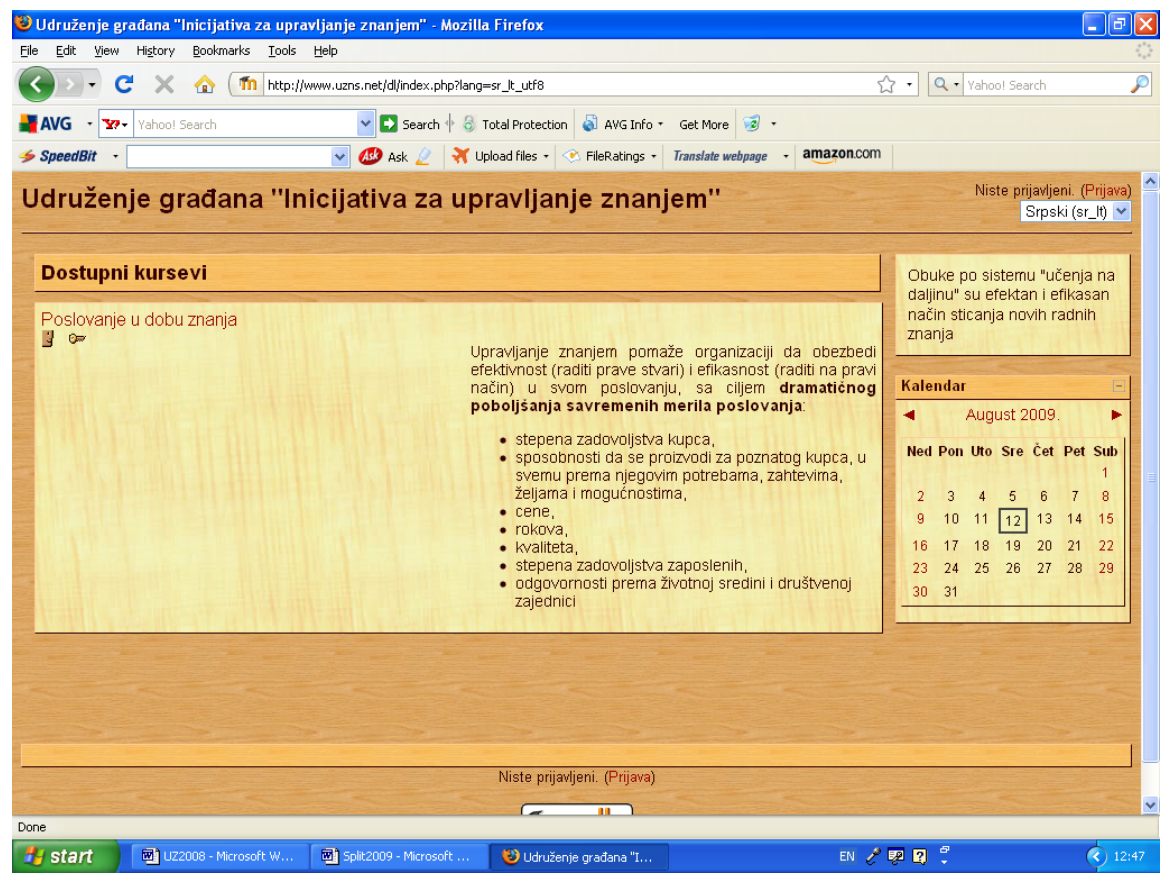

Figure 8: System for on-line courses

The idea was to offer some of the courses as 'open' (for everyone), and some to be just for registered users i.e. members who participated on the forum and in that way contributed to the life of the virtual community. This neither influenced nor improved the statistics.

Even though the membership fee was the lowest possible ( 0 euros), and the benefits, for an individual as well as the whole society, immeasurable, it proved not to be an easy task to create a knowledge community in Serbia. After this, the site was removed on 1 November 2009, and again without any reactions from the public. 


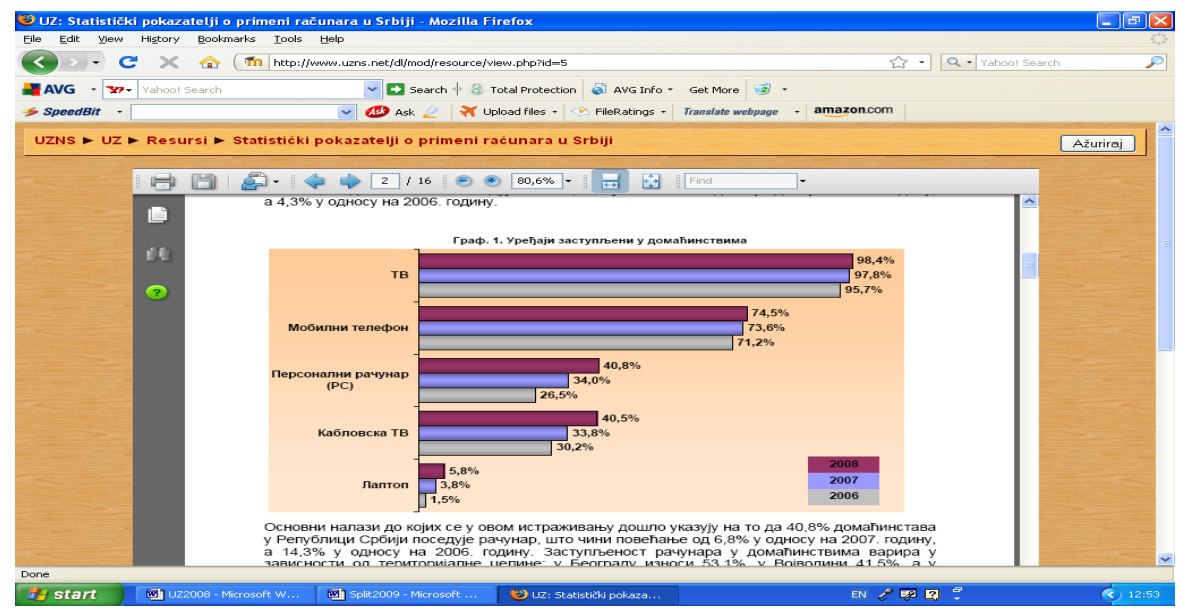

Figure 9: One of the lessons of the on-line course

\section{Conclusions}

What could be accomplished by creating a knowledge community:

- organizations would receive neccessary information, knowledge and whatever help they need in doing business. This directly influences the development of KM and other sectors connected with it in Serbia

- participants in creating new values for KM service users become connected, so product and service marketplace can function better

- better identification of needs and abilities of those who offer services/KM products, consumers, workforce, ready made products, information and knowledge

- creating, maintaining, sharing and evaluating new knowledge is easier, faster and better

- $\quad$ better and more purposeful education of professionals (future students, workforce and experts)

- entrepreneuria spirit will develop, nation's awareness about the need to create new operational knowledge will raise, also we will recognize the need to share that new knowledge, to apply it and evaluate it more properly

- all resources are used in a better way

It is obvious that in a poor society which is still experiencing transition and which has numerous problems, a virtual community could be very significat. It could be an important connection between people from a sociological, professional and scientific point of view. It could also accelerate innovation and creation of new, more effective, more efficient products, services and processes.

Initial results of creating a knowledge community were disappointing. NGO "Initiative for knowledge management" started applying the concepts of KM in practice. It offered consulting services to smaller, private, successful organizations. This was an attempt to create a critical mass of "knowledge managers" in our country. The latest idea is to approach some bigger international NGO with a project of creating a knowledge community. The received funds would then be used to promote knowledge management in the press and electronic media, also to organize lectures in bigger firms in Serbia but with the obligation for those who would get free training to actively participate in this virtual community. 


\section{References}

Feantsa Statement on the outcome of the Barcelona Summit. (2002). What about poverty? Retrieved from www.feantsa.org/files/keydocs/fea_docs/statements/feantsa_statement post_barcelona_march_2002.d $\underline{\mathrm{oc}}$

Gibson, W. (1984). Neuromancer. New York: Ace Books.

Lisbon Special European Council. (2000, March). Towards a Europe of Innovation and Knowledge. Retrieved from http://europa.eu/legislation_summaries/education training_youth/general framework/c10241 en.htm

Lovrekovic, Z. (2003). Knowledge management -The challenge of the new age. Proceedings of the 1st Conference "On the road to the knowledge age", Faculty of Management Novi Sad, Zobnatica, Serbia.

Lovrekovic, Z. (2004). What's the purpose of the knowledge management? Proceedings of the 2nd Conference "On the road to the knowledge age", Valdanos, Montenegro.

Lovrekovic, Z., \& Nikolic, D. (2004). Building of the knowledge management system. Proceedings of the 2nd Conference "On the road to the knowledge age", Valdanos, Montenegro.

Lovrekovic, Z., \& Ristic, I. (2008). Virtual communities as a knowledge management system. Proceedings of the 6th Conference "On the road to the knowledge age", Faculty of Management Novi Sad, Sremski Karlovci, Serbia.

Montano, B. (2005). Innovations of knowledge management. Hershey, PA: IRM Press. Retrieved from http://books.google.com/books?id=f3CvHIHC77oC\&pg=PA256\&lpg=PA256\&dq=UNICE+Benchmar $\underline{\mathrm{k}}-$

ing + Report $+2000 \&$ source $=$ web\&ots $=$ f40mQfHN1x\&sig=WsltB5KWBtkm8MVB1dAmC9 UH3k\&hl $=$ en\&sa $=X \&$ oi $=$ book result\&resnum $=2 \& \mathrm{ct}=$ result

Rheingold, H. (1993). The virtual community: Homesteading on the electronic frontier. Reading, Massachusetts: Addison-Wesley. ISBN 0-201-60870-7

\section{Biographies}

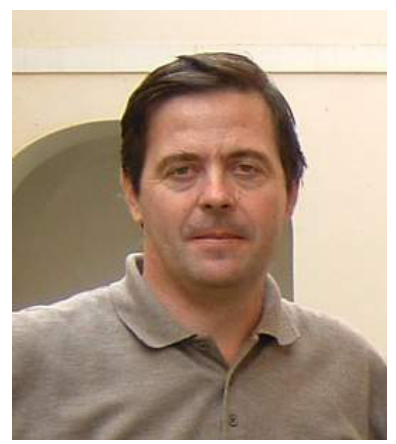

Zoran Lovrekovic is a professor at the Higher Technical School of Professional Education, Novi Sad, Serbia. He teaches courses in Applied Databases, Management Information Systems and E-Business. He received Ph.D. degree in IT (IT in production management) at the University of Novi Sad. His research interests include knowledge management systems and expert knowledge in object and internet programming

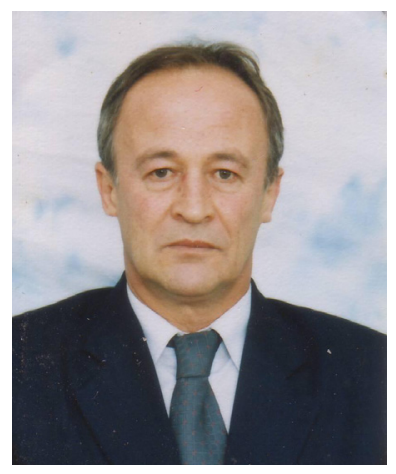

Ćamil Sukić is a full professor at the University of Novi Pazar. He graduated at Technical University and received Master and $\mathrm{PhD}$ degree at the University of Novi Sad. Scientific fields of his interest are: Information and communication technology, Security and protection of computer systems, IT in education. He is also the dean of the Department of Informatics and teaches at undergraduate, master and doctoral studies. He is a member of the Editorial board of the International Indexed scientific journal, TTEM-Technics Technologies Education Management. 